Section Editor

Mitchell S.V. Elkind, MD, MS
R. Velizarova, MD, PhD

A. Crespel, MD, PhD

R. Juntas-Morales, $\mathrm{MD}$

P. Coubes, MD, PhD

P. Gélisse, MD

Address correspondence and reprint requests to Dr. Philippe Gelisse, Explorations

Neurologiques et Epileptologie, Hôpital Gui de Chauliac, 80 avenue Fliche, 34295 Montpellier cedex 05, France

p_gelisse@hotmail.com

\title{
Teaching NeuroImages: \\ Benediction sign as a result of cervical astrocytoma with syringomyelia
}

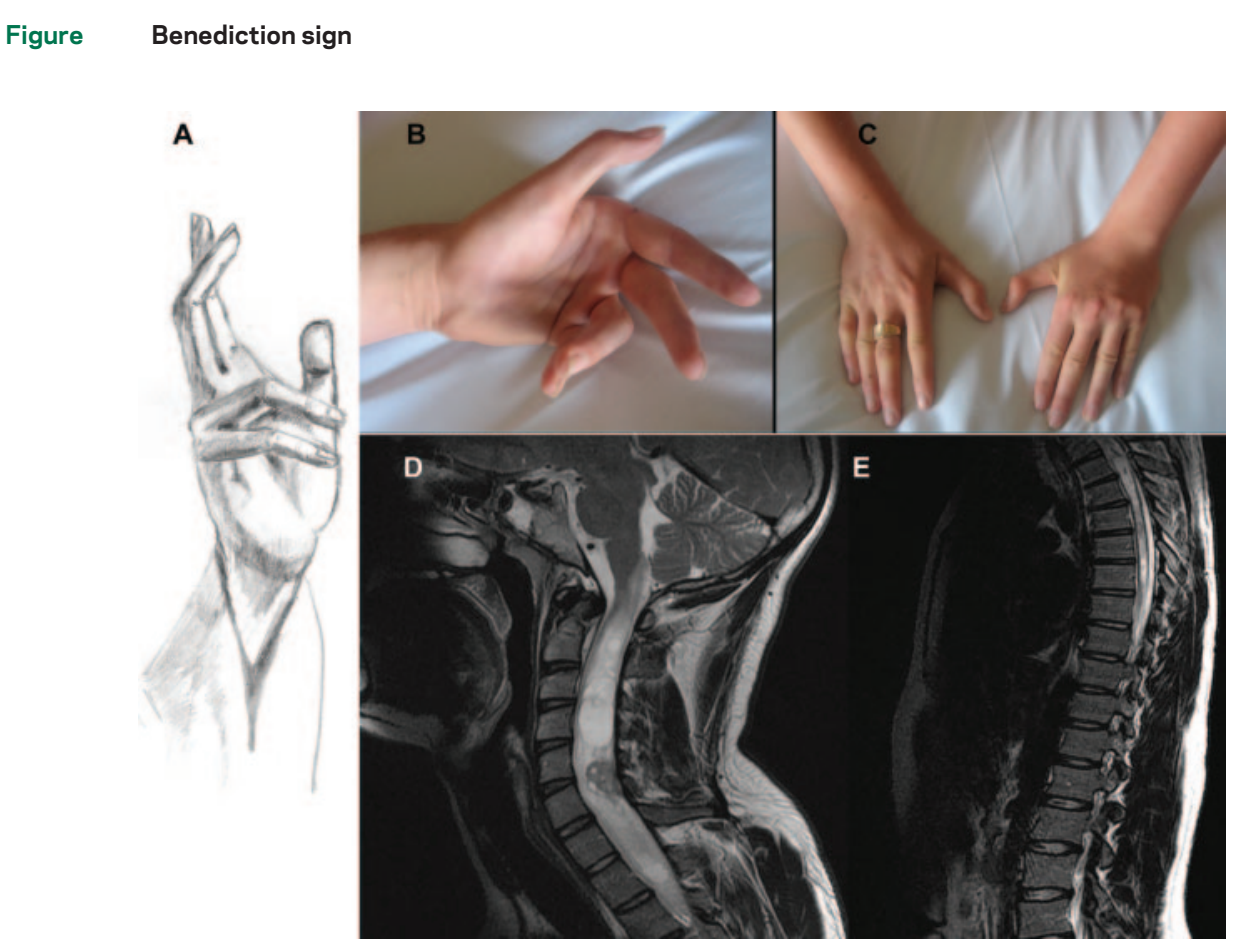

Benediction sign is a wrist position where the 3 raised fingers are allegorically interpreted in Christianity as representing the 3 Persons of the Holy Trinity (A). The left little and ring fingers do not extend (B). Note the trophic changes of the skin (C). Sagittal cervical (D) and thoracic (E) MRI show intramedullary tumor at C5-C6 with numerous cysts, and syringomyelia extending to the thoracic segment.

A 16-year-old boy developed progressive painless flexion contractures of the fourth and fifth left fingers. No amyotrophy was noted. The electroneuromyogram was unremarkable. Local steroid injections brought minimal improvement. Four years later, there was progression with similar symptoms in the right hand and involvement of the left third finger, trophic skin changes, atrophy of the interosseus muscles and thenar and hypothenar eminences, hyperreflexia, and sensory loss in the left hand (C8 territory). MRI demonstrated intramedullary tumor at C5-C6 with syringomyelia (figure). Histologic examination revealed a pilocytic astrocytoma. "Benediction sign" refers to the gesture conferring a blessing which occurs in ulnar paralysis ${ }^{1}$ and syringomyelia. ${ }^{2}$

\section{AUTHOR CONTRIBUTIONS}

Dr. Velizarova: drafting/revising the manuscript, study concept or design, analysis or interpretation of data, acquisition of data. Dr. Crespel: drafting/revising the manuscript, study concept or design, analysis or interpretation of data, study supervision. Dr. Morales: drafting/revising the manuscript, acquisition of data. Dr. Coubes: drafting/revising the manuscript, study concept or design, analysis or interpretation of data, neurosurgery. Dr. Gelisse: drafting/revising the manuscript, study concept or design, analysis or interpretation of data, contribution of vital reagents/ tools/patients, acquisition of data.

\section{REFERENCES}

1. Head H, Sherren J. The consequences of injury to peripheral nerves in man. Brain 1905;28:116-338.

2. Taylor J, Greenfield JG, Martin JP. Two cases of syringomyelia and syringobulbia observed clinically over many years, and examined pathologically. Brain 1922;45:321356. 


\section{Neurology}

\section{Teaching NeuroImages: Benediction sign as a result of cervical astrocytoma with syringomyelia}

R. Velizarova, A. Crespel, R. Juntas-Morales, et al.

Neurology 2011;77; e50

DOI 10.1212/WNL.0b013e31822c619d

This information is current as of August 29, 2011

Updated Information \& Services

References

Subspecialty Collections

Permissions \& Licensing

Reprints including high resolution figures, can be found at: http://n.neurology.org/content/77/9/e50.full

This article cites 2 articles, 0 of which you can access for free at: http://n.neurology.org/content/77/9/e50.full\#ref-list-1

This article, along with others on similar topics, appears in the following collection(s):

Adolescence

http://n.neurology.org/cgi/collection/adolescence

All Pediatric

http://n.neurology.org/cgi/collection/all_pediatric

Clinical neurology examination

http://n.neurology.org/cgi/collection/clinical_neurology_examination

MRI

http://n.neurology.org/cgi/collection/mri

Spinal cord tumor

http://n.neurology.org/cgi/collection/spinal_cord_tumor

Information about reproducing this article in parts (figures,tables) or in its entirety can be found online at:

http://www.neurology.org/about/about_the_journal\#permissions

Information about ordering reprints can be found online:

http://n.neurology.org/subscribers/advertise

Neurology ${ }^{\circledR}$ is the official journal of the American Academy of Neurology. Published continuously since 1951, it is now a weekly with 48 issues per year. Copyright Copyright (? 2011 by AAN Enterprises, Inc.. All rights reserved. Print ISSN: 0028-3878. Online ISSN: 1526-632X.

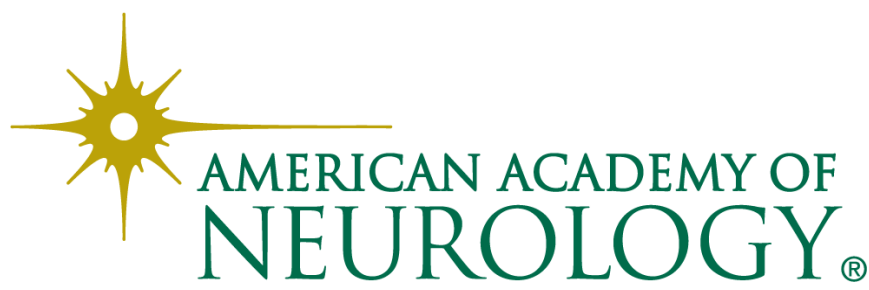

